\title{
PERAN ORANGTUA DAN PENDETA DALAM MENINGKATKAN PERILAKU MENOLONG PADA REMAJA GEREJA ALKITAB ANUGERAH BEKASI
}

\author{
Heliyanti Kalintabu \\ Desi Sianipar \\ Universitas Kristen Indonesia \\ Program Studi Magister Pendidikan Agama Kristen \\ heliyantikalintabu@yahoo.co.id \\ desi.sianipar07@gmail.com
}

\begin{abstract}
Abstrak
Pada masa kini perilaku sosial, khususnya perilaku menolong pada remaja terasa sangat kurang. Banyak remaja bersikap masa bodoh dan tidak mau menolong orang yang sedang membutuhkan. Karena itulah sikap egois pada banyak remaja telah menjerumuskan mereka pada praktik-praktik yang tidak baik, seperti: tawuran, miras, narkoba, dan lain-lain. Untuk itulah, peran orangtua dan pendeta untuk membimbing dan mengarahkan remaja menyangkut perilaku sosial sangatlah penting. Penelitian ini bertujuan untuk mengetahui sejauh mana peran orangtua dan pendeta dalam meningkatkan perilaku menolong pada remaja Gereja Alkitab Anugerah Bekasi dan mengusulkan rencana pelaksanaan pembelajaran mengenai perilaku menolong yang dapat dijalankan dengan teratur.

Pendekatan yang digunakan dalam penelitian ini adalah penelitian kualitatif deskriptif, yaitu penelitian yang bermaksud untuk memahami fenomena yang dialami oleh subjek penelitian, misalnya: perilaku, persepsi, motivasi, tindakan dan lain-lain secara holistik. Metode pengumpulan data yang digunakan dalam penelitian ini adalah metode wawancara dan observasi.

Hasil dari penelitian ini adalah orangtua dan pendeta memiliki peran yang sama dalam hal membimbing, mengarahkan, memberikan pengetahuan dan memberikan motivasi kepada remaja agar mereka memiliki perilaku sosial, khususnya menyangkut perilaku menolong. Sementara itu, penelitian ini juga menghasilkan sejumlah saran untuk dipertimbangkan oleh penulis dan pihak lain dalam studi lanjutan mengenai topik ini. Beberapa saran yang diberikan antara lain: Program Studi MPAK dapat memberikan pelatihan kepada para mahasiswa agar mampu mendesain programprogram pembelajaran menyangkut perilaku sosial remaja, khususnya perilaku menolong, baik di gereja maupun di sekolah; Orangtua lebih memperhatikan dan mengawasi perilaku remaja, memberikan waktu untuk berkomunikasi dengan anaknya, dan memberikan teladan dalam hal berperilaku menolong; Pendeta hanya membimbing dan bekerja sama dengan pengurus gereja lainnya dalam membuat rencana pelaksanaan pembelajaran mengenai perilaku menolong sehingga dapat dipahami dengan baik oleh remaja.
\end{abstract}

Kata Kunci: perilaku menolong, peran orangtua, peran pendeta, remaja. 


\section{Pendahuluan}

Tolong menolong merupakan kecenderungan alamiah manusia. Manusia mempunyai kecenderungan dasar untuk meminta dan memberikan pertolongan pada orang lain. Sebagai makhluk yang lemah, manusia membutuhkan orang lain untuk meringankan sebagian beban yang dialami. Tetapi sebagai mahluk yang dianugerahi kelebihan, manusia mempunyai kuasa dan kewajiban sosial untuk membantu meringankan beban hidup yang dialami orang lain. ${ }^{1}$ Secara universal, sikap menolong masyarakat di belahan dunia mana pun sangat disukai, yaitu: orang yang dermawan, suka menolong, koperatif, solider, dan mau berkorban untuk orang lain. Sebaliknya, orang yang kikir, egois, atau individualistis, sangat tidak disukai masyarakat. Dalam Kekristenan, perilaku menolong merupakan perilaku yang sangat dihargai dan wajib dilakukan karena Kekristenan mengajarkan kasih, baik kasih kepada Allah maupun kasih kepada sesama manusia sebagaimana yang terdapat dalam Matius 22:37,39: "Jawab Yesus kepadanya: Kasihilah Tuhan, Allahmu, dengan segenap hatimu dan dengan segenap jiwamu dan dengan segenap akal budimu", dan hukum yang kedua, yang sama dengan itu, ialah: kasihilah sesamamu manusia seperti dirimu sendiri". Berdasarkan ayat tersebut orang Kristen harus menerapkan kasih yang bersifat menolong kepada orang lain.

Di era globalisasi bangsa Indonesia diperhadapkan pada rendahnya kesadaran sosial pada masyarakat. Krisis sosial sudah sampai pada bentuk yang cukup memprihatinkan. Berbagai bentuk kemiskinan sosial banyak diperlihatkan, seperti: miskin pengabdian, kurang disiplin, kurang empati, kurang efektif, dan egois. Data menunjukkan lebih dari 7.000 anak merupakan pelaku tindak pidana yang masuk proses peradilan setiap tahun di mana 5 (lima) jenis tindak pidana yang paling

\footnotetext{
${ }^{1}$ Agus Abdul Rahman, Psikologi Sosial (Jakarta: Raja Grafindo Persada, 2014), 218.
}

dominan dilakukan anak-anak remaja, yaitu: pencurian, narkotika, asusila, penganiayaan dan pengeroyokan. ${ }^{2}$ Data-data tersebut menunjukkan krisis perilaku menolong.

Berdasarkan pengamatan penulis, peranan orangtua dan pendeta di dalam pengajaran pendidikan agama Kristen sangat berpengaruh terhadap perkembangan perilaku remaja, khususnya perilaku menolong. Keteladanan orangtua dan pendidikan agama yang diajarkan oleh pendeta sangat membantu remaja dalam perkembangannya, khususnya menyangkut perilaku menolong.

\section{Tinjauan Teoritis}

\section{A. Perilaku Menolong}

\section{Pengertian Perilaku Menolong}

Dalam Kamus Besar Bahasa Indonesia, perilaku adalah tanggapan atau reaksi individu terhadap rangsangan atau lingkungan. Menolong artinya membantu untuk meringankan beban (penderitaan, kesukaran, dan sebagainya). Jadi, perilaku menolong adalah tanggapan atau reaksi individu dalam membantu meringankan beban orang lain di lingkungan mana saja seseorang itu berada. Menurut Koentjoro, perilaku menolong (helping behavior) adalah sebuah tindakan menolong yang dilakukan secara terus-menerus atau berulang-ulang sehingga membentuk perilaku menolong. ${ }^{3}$

Clarke membedakan perilaku menolong berdasarkan motif yang melatarbelakanginya. Menurutnya, ada perilaku menolong yang didorong oleh motif egoisme dan ada juga perilaku menolong yang didorong oleh motif altruistik. ${ }^{4}$ Perilaku menolong disebut egois jika didorong oleh

\footnotetext{
${ }^{2}$ http://smslap.ditjenpas.go.id/public/grl/detail/dail y/upt/db6103f0-6bd1-1bd1-cadc-313134333039 diunduh pada 2 Maret 2016.

${ }^{3}$ Koentjoro bin Soeparno, Psychology Human Development (Malaysia: Universitas Kebangsaan Malaysia, 2013), 1.

${ }^{4}$ Motif altruistik adalah motif yang didasari oleh perhatian terhadap kesejahteraan orang lain tanpa memperhatikan diri sendiri.
} 
kepentingan diri sendiri, misalnya untuk mendapatkan perasaan lebih nyaman, ingin disebut pahlawan, ingin mendapatkan pujian, atau sekedar untuk menghindari perasaan bersalah. Perilaku sosial yang didorong oleh motif altruisme didorong oleh keinginan untuk memberikan keuntungan pada orang lain dan cukup berisiko bagi si altruisnya. ${ }^{5}$ Dalam penelitian ini, perilaku menolong yang dimaksud adalah segala tindakan yang menguntungkan orang lain secara terusmenerus, yang kadang-kadang akan memberi resiko bagi si penolong.

\section{Bentuk-Bentuk Perilaku Menolong}

Mengenai bentuk-bentuk perilaku menolong, Peace dan Amato menggambarkannya dengan membuat taksonomi dalam tiga dimensi. Ketiga dimensi tersebut adalah:

- Berdasarkan setting sosialnya, perilaku menolong bisa bersifat terencana dan formal, atau spontan dan tidak formal. Perilaku menolong yang bersifat terencana dan formal, misalnya mengadopsi anak yatim, sedangkan perilaku menolong yang tidak formal dan tidak direncanakan, misalnya meminjamkan pensil.

- Berdasarkan keadaan yang menerima pertolongan, perilaku menolong dapat dikategorikan menjadi perilaku menolong yang bersifat serius atau tidak serius. Perilaku menolong yang serius, misalnya mendonorkan ginjal, dan perilaku menolong yang tidak serius, misalnya menunjukkan arah jalan.

- Berdasarkan jenis pertolongannya, perilaku menolong bisa bersifat mengerjakan secara langsung atau tidak langsung, yaitu menunjuk pada apakah pertolongan tersebut diberikan secara langsung kepada korban atau melalui orang ketiga. Perilaku menolong yang sifatnya langsung,

\footnotetext{
${ }^{5}$ Clark-Carter, Quantitative Psychological Research: A Student's Handbook (USA and Canada: Psychology Press, 2004), 220.
}

misalnya menjadi relawan di dalam membantu korban bencana, sedangkan perilaku menolong yang bersifat tidak langsung, yaitu memberikan sumbangan kepada korban bencana melalui lembaga tertentu. ${ }^{6}$

Menurut Mc. Guire, sebagaimana dikutip Agus Abdul Rahman, terdapat empat jenis perilaku menolong, antara lain: ${ }^{7}$

- Casual helping, yaitu memberikan pertolongan yang sifatnya biasa/umum, misalnya meminjamkan pulpen kepada teman.

- Substantial personal helping, yaitu pertolongan yang membutuhkan usaha yang dapat menguntungkan orang lain, misalnya membantu teman pindah rumah.

- Emotional helping, yaitu pertolongan dengan memberikan dukungan emosional atau sosial, misalnya mendengarkan cerita teman tentang masalah pribadinya.

- Emergency helping, yaitu pertolongan bersifat darurat. Misalnya, memberi pertolongan pada orang asing yang terkena serangan jantung atau kecelakaan lalu lintas.

\section{Faktor-Faktor yang Mempengaruhi Perilaku Menolong}

Sebagaimana perilaku sosial lainnya, perilaku menolong terbentuk karena banyak faktor. Faktor personal, interpersonal, dan situasional berpengaruh terhadap munculnya perilaku menolong. Faktor-faktor tersebut memberikan kontribusi secara berbeda-beda tergantung dari kasusnya. Kasus perilaku menolong mungkin lebih banyak dipengaruhi oleh faktor personal dan kasus lainnya mungkin lebih dipengaruhi oleh faktor interpersonal dan situasional. ${ }^{8}$

\footnotetext{
${ }^{6}$ Agus Abdul Rahman, Op.Cit., 222-223.

${ }^{7}$ Ibid, 223.

${ }^{8}$ Ibid, 224.
} 
Selanjutnya, Agus Abdul Rahman menyatakan bahwa perilaku menolong dapat dijelaskan dari empat perspektif, yakni: ${ }^{9}$

- Perspektif Evolusionis. Perspektif evolusionis menjelaskan bahwa perilaku menolong bersifat genetik. Secara genetik, manusia dianggap mempunyai kecenderungan untuk menolong orang lain. Berbagai fakta memang menunjukkan kebenaran tersebut. Fakta-fakta tersebut antara lain: terdapatnya bukti ilmiah bahwa hewan pun ternyata mempunyai kecenderungan untuk menolong. Penulisan mutakhir yang dilakukan oleh Inbal Ben-Ami Bartal, Jean Decety dan Peggy Mason pada tahun 2011 mengidentifikasi bahwa empati juga dimiliki oleh binatang mengerat seperti tikus, dan empati tersebut mendorong tikus untuk melakukan perilaku menolong terhadap temannya. Fakta lainnya yang berhubungan dengan sifat genetik adalah adanya kecenderungan manusia untuk menunjukkan perilaku altruis, terutama terhadap orang-orang yang memiliki hubungan kekerabatan. Manusia memiliki kecenderungan alamiah untuk menjaga dan melindungi kelompok atau kerabatnya sendiri. Kecenderungan itu memungkinkan seseorang untuk membela atau menolong kerabatnya walaupun harus mengambil risiko dan mengorbankan dirinya sendiri. Tujuannya jelas bukanlah self-serving, tetapi lebih pada bagaimana menjaga keberlangsungan hidup kelompok atau kerabatnya. Misalnya, seorang ibu mempunyai kecenderungan alamiah untuk melakukan pengasuhan dan perawatan terhadap anaknya. Motivasi tersebut jauh dari motivasi yang bersifat egoistik. Kecenderungan tersebut secara alamiah diperoleh seorang ibu tanpa melalui proses belajar. ${ }^{10} \quad$ Fakta

berikutnya yang berhubungan dengan sifat genetik adalah empati. Empati merupakan

\footnotetext{
${ }^{9}$ Ibid, 224-226.

${ }^{10}$ Schroeder, Penner, Dovidio \& Piliavin, The

Psychology of Helping and Altruism (USA:

Mcgraw Hill, 1995), 224.
}

salah satu faktor yang secara ilmiah terbukti berpengaruh terhadap perilaku menolong. Empati ini bisa merupakan salah satu alasan genetik dari perilaku altruisme. Limbic system ${ }^{11}$ dalam otak memungkinkan manusia secara fisiologis $^{12}$ atau neurologis ${ }^{13}$ berempati terhadap orang lain. Menurut Duan, empati meliputi komponen afektif dan kognitif. Secara afektif, orang yang berempati merasakan apa yang orang lain rasakan. Secara kognitif, orang yang berempati memahami apa yang orang lain rasakan dan mengapa dia merasakannya. Tulisan Martin dan Clark juga menunjukkan bahwa kemampuan berempati sudah dimiliki sejak usia dini. Anak usia satu hari menunjukkan tangisan yang lebih keras ketika diperdengarkan suara tangisan bayi seusianya, daripada ketika diperdengarkan suara tangisan dirinya sendiri. ${ }^{14}$

- Perspektif Belajar Sosial. Perilaku menolong bisa juga dijelaskan dengan menggunakan perspektif belajar sosial (social learning). Perspektif belajar sosial menjelaskan bahwa perilaku menolong terjadi karena proses belajar dari pengalaman dan pengamatan bahwa menolong dapat menguntungkan. Seorang anak mengembangkan perilaku menolong salah satunya melalui proses modeling atau peniruan terhadap orang-orang di sekitarnya, terutama perilaku menolong yang ditunjukkan oleh orang-orang yang dianggap penting. Selain itu, perilaku menolong bisa juga terbentuk karena pengalaman-pengalaman sebelumnya yang menyatakan bahwa perilaku me-

\footnotetext{
${ }^{11}$ Limbic system adalah suatu bagian otak yang berfungsi menyimpan informasi dan mengeluarkannya kembali ketika dibutuhkan.

${ }^{12}$ Fisiologis adalah cabang biologi yang berkaitan dengan fungsi dan kegiatan kehidupan atau zat hidup (organ, jaringan, atau sel).

${ }^{13}$ Neurologis adalah istilah kedokteran yang bersifat atau menurut ilmu urat saraf.

${ }^{14}$ Baron \& Byrne, Social Psychology (New York: Pearson Education, 2003), 111.
} 
nolong dapat memberikan keuntungan atau menghindar dari hal-hal yang negatif. Orang akan cenderung mengulang perilaku menolong jika perilaku tersebut dipandang menguntungkan atau menghindarkan diri dari kerugian. Jane Piliavin, dkk. mengembangkan costreward models untuk menjelaskan pengaruh pertimbangan untung rugi terhadap perilaku menolong. Menolong atau tidak menolong sebenarnya mengandung risiko dan reward. Pertimbangan terhadap risiko dan reward tersebut berpengaruh pada bagaimana perilaku menolong seseorang. Jika risiko tidak menolong kecil dan risiko menolong besar, maka orang akan cenderung menghindari perilaku menolong. Sebaliknya jika risiko perilaku menolong rendah dan risiko tidak menolong tinggi, maka orang akan cenderung menunjukkan perilaku menolong.

- Perspektif Sosial-Kultural. Perspektif sosial-kultural menjelaskan bahwa perilaku menolong lebih banyak dipengaruhi oleh faktor kultural. Dalam banyak budaya terdapat norma-norma yang menjunjung dan mendorong masyarakatnya untuk menunjukkan perilaku prososial. Norma-norma tersebut disosialisasikan dari generasi ke generasi sehingga norma-norma tersebut dihayati dan masyarakat kemudian mempunyai kecenderungan untuk melakukan perilaku prososial. Norma-norma tersebut antara lain norma resiprokal, yaitu kecenderungan untuk menolong orang yang pernah berbuat baik, sedangkan norma tanggung jawab sosial, yaitu kecenderungan untuk menolong orang lain karena dia berada dalam tanggung jawab si penolong.

- Perspektif Sosial-Kognitif. Perspektif ini memandang perilaku prososial sebagai hasil dari pertimbangan kognitif. Salah satu teori yang menggunakan perspektif sosial-kognitif adalah teori model pengambilan keputusan untuk menolong. Seseorang akan menjalankan hasil pertimbangan kognitif yang kadang terjadi di luar kesadarannya, di mana langkahlangkahnya sebagai berikut: 1) Memerhatikan bahwa ada sesuatu yang salah, dipengaruhi oleh kejelasan stimulus ${ }^{15}$ dan stimulus overload. ${ }^{16} ; 2$ ) Menginterpretasi bahwa sesuatu yang salah itu membutuhkan pertolongan, yang dipengaruhi oleh isyarat persepsi, informasi sosial, hubungan dengan korban dan risiko; 3) Merasa bertanggungjawab secara personal untuk menolong yang dipengaruhi oleh norma, kehadiran orang lain, hubungan dengan korban dan risiko; 4) Memilih cara untuk memberikan pertolongan, yang dipengaruhi oleh pengetahuan dan pelatihan; 5) Mengambil keputusan dan memberikan pertolongan, yang dipengaruhi oleh pelatihan dan pengalaman.

Penjelasan lain mengenai faktor yang mendorong seseorang melakukan perilaku menolong adalah faktor emosi. Menolong dapat dilakukan karena bangkitnya emosi negatif $^{17}$ ketika melihat orang lain yang menderita. Timbulnya emosi negatif ini dapat mendorong perilaku menolong, akan tetapi emosi negatif ini cenderung bersifat egoistik atau self serving yaitu: perilaku menolong tersebut ditujukan untuk menghilangkan emosi negatif yang dialaminya. ${ }^{18}$ Terdapat tiga asumsi pada model ini, yaitu: 1) Emosi negatif dapat memotivasi orang untuk menolong yang bisa bersumber dari beberapa jenis emosi, misalnya: perasaan bersalah karena pernah menyakiti orang atau salah sasaran, perasaan sedih karena menyaksikan orang yang tidak beruntung; 2) Menolong dianggap sebagai salah satu cara yang dapat membuat perasaan lebih baik; 3) Emosi negatif dapat meningkatkan perilaku me-

\footnotetext{
${ }^{15}$ Stimulus adalah perangsang, pendorong, dorongan.

${ }^{16}$ Stimulus overload adalah stimulus yang berlebihan.

${ }^{17}$ Emosi negatif mengekspresikan sebuah evaluasi atau perasaan merugikan, misalnya: sedih, menangis, marah, kecewa, benci dan lainlain.

${ }^{18}$ Ibid, 228
} 
nolong jika dipercayai bahwa perilaku menolong dapat menghilangkan perasaan negatif. ${ }^{19} \quad$ Menurut empathy-altruism hypothesis dari Batson, emosi empati juga bisa mendorong perilaku altruis, yaitu menolong dengan tujuan untuk meningkatkan kesejahteraan orang lain, tidak egoistik. Sebenarnya, empati tidak hanya mengandung unsur emosi, tetapi juga mengandung unsur kognitif. Unsur kognitifnya adalah perspective taking atau memandang sesuatu dengan menggunakan perspektif orang lain, sedangkan unsur emosinya adalah perasaan tidak nyaman ketika melihat orang yang membutuhkan pertolongan (personal distress) dan perasaan kasihan, simpati, ataupun kasih sayang ketika melihat orang yang membutuhkan pertolongan (empathic concern.$^{20}$

\section{B. Remaja dan Perkembangannya}

\section{Pengertian Remaja}

Pengertian remaja dalam Kamus Besar Bahasa Indonesia adalah mulai dewasa; sudah sampai umur untuk kawin: bukan kanak-kanak lagi. ${ }^{21}$ Dalam bahasa Latin remaja dikenal dengan sebutan puber yang berasal dari kata pubertas. Pengertian pubertas berkaitan dengan tercapainya tanda kematangan fisik. Dalam masa ini terlihat pula perkembangan psikososial yang berhubungan dengan berfungsinya seseorang dalam lingkungan sosial, yakni dengan melepaskan diri dari ketergantungan pada orangtua, pembentukan rencana hidup dan pembentukan sistem nilai-nilai. ${ }^{22}$

Istilah remaja atau adolescentia berasal dari bahasa Latin. Berbeda dengan pengertian pubertas yang berkaitan dengan tercapainya

\footnotetext{
${ }^{19}$ Schroeder, Penner, Dovidio \& Piliavin. Op.Cit., 224.

${ }^{20}$ Brehm \& Kassin, Social Psychology (USA: Houghton Mifflin Co, 1996), 117.

${ }^{21}$ Kamus Besar Bahasa Indonesia mobile.

${ }^{22}$ Singgih Gunarsa \& Yulia Singgih, Psikologi Perkembangan Anak dan Remaja (Jakarta: BPK Gunung Mulia, 2008), 201-202.
}

tanda kematangan fisik, adolescentia dikaitkan dengan masa yang berbeda-beda. Dari kepustakaan Belanda dapat disimpulkan bahwa adolescentia dimulai sesudah tercapai kematangan seksual secara biologis, sesudah pubertas. Jadi, adolescentia adalah masa perkembangan sesudah masa pubertas, yakni antara 17 tahun dan 22 tahun. Adolescence dari bahasa Inggris menunjukkan masa peralihan dengan semua perubahan psikis, yakni antara umur 12 tahun dan 22 tahun. ${ }^{23}$ Istilah adolesensia diartikan secara luas meliputi semua perubahan. Remaja merupakan masa peralihan antara masa anak dan masa dewasa yakni antara 12-21 tahun. Mengingat pengertian remaja menunjukkan ke masa peralihan sampai tercapainya masa dewasa, maka sulit menentukan batas umurnya. Masa remaja mulai pada saat timbulnya perubahan-perubahan berkaitan dengan tanda-tanda kedewasaan fisik, yakni pada umur 11 tahun atau mungkin 12 tahun pada wanita dan pada laki-laki lebih tua sedikit. Berakhirnya masa remaja sulit ditentukan mengingat pengertian "mandiri" yang berbeda-beda. Masyarakat yang majemuk dengan kebudayaan dan peradaban yang tinggi memerlukan masa remaja yang panjang untuk menjalani semua persiapan pendewasaan agar mampu hidup "mandiri". Makin tinggi taraf kehidupan suatu masyarakat, makin tinggi tuntutan hidup bagi remaja dan tantangan hidup yang harus diimbangi dengan kemampuan yang meningkat melalui persiapan yang lebih lama. Dengan demikian dapat disimpulkan bahwa remaja masa kini bisa mencapai masa dewasa pada umur 20-21 tahun. ${ }^{24}$

\section{Tugas-tugas Perkembangan Remaja}

Pada remaja terdapat beberapa tugas perkembangan yang harus dipenuhi. Menurut Hurlock, tugas perkembangan remaja antara lain: ${ }^{25}$

\footnotetext{
${ }^{23}$ Ibid, 202.

${ }^{24}$ Ibid, 204.

${ }^{25}$ Elizabeth Hurlock, Psikologi Perkembangan (Jakarta: Erlangga, 1999), 218.
} 
- Mencapai hubungan baru yang lebih matang dengan teman sebaya sejenis atau lawan jenis. Remaja belajar untuk bergaul dengan baik, dalam hal ini remaja berusaha untuk dapat menarik perhatian lawan jenis.

- Mencapai peran sosial pria dan wanita. Remaja belajar untuk memerankan peran seks yang diakui sesuai dengan adanya tuntutan dari lingkungan.

- Menerima keadaan fisiknya dan menggunakan tubuhnya secara efektif. Remaja diharapkan dapat menyesuaikan diri dengan perkembangan fisik yang terjadi padanya dan diharapkan sudah tidak lagi mengalami kecanggungan.

- Mengharapkan dan mencapai perilaku sosial yang bertanggungjawab. Perilaku sosial remaja diharapkan dapat sesuai dengan tuntutan sosial yang ada di lingkungannya.

- Mencapai kemandirian emosional dari orangtua atau orang dewasa lainnya. Remaja diharapkan dapat membawa diri di mana pun dia berada dan tidak bergantung pada orang lain. Ada suatu tuntutan bahwa remaja harus mampu mandiri, bukan dalam hal ekonomi tetapi dalam kehidupan sosial.

- Mempersiapkan karir ekonomi. Remaja diharapkan mulai menata masa depannya sebagai masa persiapan bekerja.

- Mempersiapkan perkawinan dan keluarga. Remaja mulai membangun hubungan dengan lawan jenis namun bukan sematamata bersenang-senang tetapi untuk mencari pasangan hidup.

Berdasarkan pemaparan di atas, tugas perkembangan remaja yang berhubungan dengan perilaku menolong adalah mengharapkan dan mencapai perilaku sosial yang bertanggungjawab, dan diharapkan dapat sesuai dengan tuntutan sosial yang ada di lingkungannya.

\section{Peran Orangtua dalam Meningkatkan Perilaku Menolong}

\section{Pengertian Orangtua}

Dalam Kamus Besar Bahasa Indonesia, orangtua adalah ayah ibu kandung. ${ }^{26}$ Orangtua (ayah, ibu) adalah orang yang melahirkan anak sekaligus bertanggung jawab membesarkannya dan mendidiknya sampai dewasa baik jasmani maupun rohani. Orangtua juga merupakan pihak paling dekat dengan anak yang diharapkan dapat menjadi pembimbing terbaik bagi anak-anaknya. Orangtua adalah orang yang dituakan dan mampu menjadi panutan sekaligus dapat memberikan wejangan-wejangan baik dalam keluarga, lingkungan maupun dalam jemaat. $^{27}$

Orangtua adalah ayah dan ibu yang hidup bersama dalam ikatan pernikahan, di mana ibu telah melahirkan anak dan bertanggungjawab untuk membina anakanaknya dengan memberikan pendidikan, perhatian, kasih sayang dengan tekun dan sabar dan aktif mendorong anak-anaknya untuk mengenal Allah dengan benar. Orangtua juga membimbing anaknya dengan cara memberikan contoh yang baik dalam menjalani kehidupan sehari-hari.

\section{Peran Orangtua Sebagai Pendidik}

Sebagai orang Kristen, orangtua percaya bahwa anak adalah karunia Tuhan yang dipercayakan dalam pemeliharaan dan didikan orangtua. Pendidikan Agama dalam Perjanjian Lama dimulai dari perpindahan Abraham dari daerah sekitar sungai Efrat dan Tigris menuju Kanaan. Allah berjanji kepada Abraham bahwa keturunannya akan menjadi bangsa yang besar. "Aku akan membuat engkau menjadi bangsa yang besar, dan memberkati engkau serta membuat namamu masyhur; dan engkau akan menjadi berkat.

\footnotetext{
${ }^{26}$ Kamus Besar Bahasa Indonesia

${ }^{27}$ Jariah, Jurnal Pentingnya Pendidikan Agama

Kristen dalam Keluarga Sebagai Dasar

Pertumbuhan Kerohanian Anak. 49
} 
Aku memberkati orang-orang yang akan memberkati engkau, dan mengutuk orangorang yang mengutuk engkau dan olehmu semua kaum di muka bumi akan mendapat berkat (Kej. 12:2-3).

Umat Yahudi pada umumnya dan setiap keluarga pada khususnya ditugaskan untuk menyampaikan kekayaan iman bangsa pilihan Allah ini kepada generasi baru. Pusat pendidikan agama terletak pada keluarga terutama ayah yang bertanggungjawab dalam pendidikan agama dalam keluarganya. ${ }^{28}$ Oleh karena itu, di dalam Perjanjian Lama, kita menjumpai bahwa Tuhan mewajibkan orangtua untuk mendidik anak-anaknya dalam iman dan kasih kepada Tuhan dan sesama. Contoh yang paling konkrit ada dalam Ulangan pasal 6:1-7. Setelah Tuhan memberikan hukum-hukumnya kepada bangsa Israel sebagai umat Tuhan pada waktu itu, mereka sendiri harus berpegang dan menjalankan hukum-hukum Tuhan itu. Tetapi selanjutnya ada keharusan pula untuk mengajarkannya kepada anak-anaknya berulang kali dan membicarakannya pada waktu duduk di rumah, atau sedang dalam perjalanan, apabila sedang berbaring atau bangun. Jadi di sini, kewajiban mendidik itu dilakukan tidak saja secara verbal, tetapi juga dengan contoh hidup melalui kehidupan mereka bersama-sama dengan anak-anak mereka. Begitu juga dalam Amsal Salomo, sangat kuat sekali kesan tentang tanggung jawab orangtua dalam mendidik anaknya. ${ }^{29}$ Amsal 23: 19-21 "Hai anakku, dengarkanlah, dan jadilah bijak, tunjukanlah hatimu ke jalan yang benar. Janganlah engkau ada di antara peminum anggur dan pelahap daging. Karena si peminum dan si pelahap menjadi miskin, dan kantuk membuat orang berpakaian compang camping". Ayat ini membuktikan bahwa orangtua sebagai pendidik merupakan perintah dari Tuhan.

Di dalam Perjanjian Baru, meskipun tidak terlalu banyak, Paulus memperingatkan dengan tegas kepada para ayah untuk

\footnotetext{
${ }^{28}$ Paulus Lilik Kristianto, Prinsip dan Praktik Pendidikan Agama Kristen (Yogyakarta: ANDI, 2006), 9.

${ }^{29}$ Daniel Nuhamara, Op.Cit., 59.
}

mendidik anak-anak mereka dalam ajaran dan nasihat Tuhan (Ef. 6:1-4). Iman Timotius menurut Paulus adalah hasil didikan dari nenek dan ibunya. Semua yang telah dikatakan di atas menyungguhkan (mengonfirmasi) bahwa keluarga dalam hal ini orangtua (ayah dan ibu) mempunyai tanggung jawab mendidik anak-anak mereka di dalam iman kepada Tuhan dan cara hidup yang sesuai dengan kehendak Tuhan. ${ }^{30}$ Orangtua berkewajiban untuk mendidik anak-anaknya. Artinya tidak ada lembaga lain yang melebihi hak orangtua dalam mendidik anak-anaknya. Baik kewajiban maupun hak orangtua untuk mendidik anakanaknya dapat dilihat secara logis dari kepercayaan bahwa anak-anak adalah karunia Tuhan. Melalui orangtua dan di tangan orangtualah tugas pendidikan itu diberikan. Karena itu, orangtua mempunyai keutamaan (primacy) dalam hak dan kewajiban untuk mendidik anak-anaknya. Negara misalnya, tidak dapat merampas keutamaan hak dan kewajiban ini terutama yang menyangkut isi pendidikan khususnya di bidang iman. ${ }^{31}$

Chrysostomus menyebutkan peran orangtua sebagai pendidik. Bagi dia, tujuan PAK adalah seperti menjadi seorang olahragawan bagi Kristus. Seorang olahragawan yang berhasil adalah orang yang amat berdisiplin dalam arti melatih diri terusmenerus. Demikian pula seorang Kristen wajib dididik di bawah bimbingan dan pengawasan yang tegas. ${ }^{32}$ Comenius menyebutkan bahwa anak tidak melatih diri secara spontan, tetapi dia dibentuk oleh orangtua yang tidak mengenal lelah dalam usahanya mendidik. Mereka wajib mendidik anak tentang segala sesuatu yang berhubungan dengan pengetahuan dan takut akan Tuhan. Tugas ini dilakukan ketika anak berada di rumah, berjalan, dan berbaring. Doa pun hendaknya mendarah daging dalam lingkungan rumah tangga. Kalau orangtua

\footnotetext{
${ }^{30}$ Daniel Nuhamara, Op.Cit., 59.

${ }^{31}$ Ibid, 60.

${ }^{32}$ Robert Boehlke, Sejarah Perkembangan Pikiran \& Praktek Pendidikan Agama Kristen: dari Plato sampai I.G Loyola (Jakarta: BPK Gunung Mulia, 2011), 116.
} 
Kristen selalu berdoa sebelum dan sesudah lahirnya si bayi, maka suasana akan timbul dan turut menanamkan nilai-nilai Kristen dalam diri si anak. Comenius melihat peran orangtua sebagai pengajar seharusnya dimulai sebelum bayi lahir. Sesudah bayi lahir, orangtua mengajarkannya mutu kehidupan yang berlaku dalam segala hubungan bersamanya dan memupuk kesadarannya akan hak istimewa yang Allah karuniakan kepadanya (Ef. 6:4b). Orangtua hendaknya berdoa bersama-sama dengan anak dan mengajarnya berdoa. Anak-anak harus mendengar cerita-cerita Alkitab, nyanyiannyanyian rohani yang dia dengar dalam kebaktian, membicarakan dua tiga unsur dari kebaktian, dan memancing tanggapan dari anak. Di samping itu, orangtua haruslah waspada terhadap setiap keprihatinan yang dikemukakan anak dengan berusaha untuk mendengarkannya pada saat ia menyampaikannya. ${ }^{3}$

Luther menyebutkan peran orangtua yaitu sebagai pengajar sebagaimana ditentukan Tuhan. Mereka diperintahkan Tuhan memenuhi tugas mulia itu. "didiklah mereka di dalam ajaran dan nasihat Tuhan" (Ef. 6:4b). Untuk menolong mereka melaksanakan mandat tersebut, Luther menyusun katekismusnya. Dengan buku katekismus dalam tangan orangtua, setiap anak dapat diajar memahami intisari iman Kristen. ${ }^{34}$ Daniel Nuhamara menyebutkan bahwa keluarga merupakan setting pertama dan utama dari Pendidikan Agama Kristen. Keluarga dikatakan sebagai setting utama dan pertama tidak lain karena peranan orangtua dalam mengasuh anak-anaknya adalah sangat penting. Bukan hanya anak yang belajar dan mengalami pertumbuhan di dalam setting keluarga, tetapi sesungguhnya seluruh anggota keluarga dapat saling belajar dari

\footnotetext{
${ }^{33}$ Robert Boehlke, Sejarah Perkembangan Pikiran dan Praktek Pendidikan Agama Kristen: dari Yohanes Amos Comenius sampai Perkembangan PAK di Indonesia (Jakarta: BPK Gunung Mulia, 2010), 59.

${ }^{34}$ Robert Boehlke, Sejarah Pikiran dan Praktek Pendidikan Agama Kristen: dari Plato sampai I.G Loyola, Op. Cit., 343.
}

yang lain melalui interaksi satu sama lain. Ketika orangtua menjalankan peranan pendidikannya terhadap anak, ia sendiri belajar untuk bertumbuh dalam iman, tindakan atau sikap, bahkan pengetahuan. ${ }^{35}$

\section{Peran Orangtua Sebagai Ayah dan Ibu}

Ayah dan ibu bertanggung jawab untuk memelihara kebutuhan anak, baik secara jasmani dan rohani, guna mempertahankan hubungan yang baik di antara mereka. ${ }^{36}$ Mencari nafkah merupakan tugas yang berat. Pekerjaan mungkin dianggap hanya sebagai suatu cara untuk memenuhi kebutuhan utama dan kelangsung-an hidup. Anak yang melihat ibu dan ayah bekerja, atau ayah saja bekerja akan menyadari bahwa tanggung jawab dan kewajiban harus dilaksanakan tanpa paksaan. Tujuan akhirnya adalah anak memperoleh bahan pemikiran dan pilihan peran mana yang kelak akan dimainkan. ${ }^{37}$ Seorang ayah adalah pelindung dan tokoh otoritas dalam keluarga. Dengan sikapnya yang tegas dan penuh wibawa akan menanamkan sikap-sikap patuh terhadap otoritas dan disiplin pada anak. Ayah memberikan tugas kepada anak dengan melihat kemampuan anak untuk menyelesaikan tugas itu. Dengan kemampuan menyelesaikan tugas, anak mengetahui kemampuan dan batas-batas yang harus dia lakukan. ${ }^{38}$

Kesatuan pandangan dan tujuan pendidikan ayah-ibu merupakan landasan penting bagi perkembangan anak. Disiplin orangtua dalam berbagai aspek, akan dicontoh oleh anak, sehingga menjadi sikap disiplin pada anak. Dengan demikian terlihat bahwa kesepakatan ayah dan ibu dapat menjadi landasan bagi terciptanya suasana keluarga yang sejahtera. Semua usaha harus berpangkal pada kesepakatan ayah-ibu. Ayah dan ibu sedapat mungkin memiliki satu

\footnotetext{
${ }^{35}$ Daniel Nuhamara, Op. Cit., 57.

${ }^{36}$ Mary Go Setiawani, Op. Cit., 11-12.

${ }^{37}$ John Virgil Milla, Op.Cit., 13-16.

${ }^{38}$ Ibid.
} 
falsafah hidup dalam hubungannya dengan anak mereka. ${ }^{39}$

\section{Peran Orangtua Sebagai Teman}

Orangtua tidak boleh selalu menampilkan wajah yang serius sehingga anak tidak berani mendekat. Orangtua harus menjadi teman akrab bagi anaknya, hidup bersama mereka, kadangkala perlu ikut bereaksi, mendampingi mereka bermain. Dengan demikian hubungan baik antara ayah dan anak terjalin, sehingga orangtua bisa menjadi penghibur sewaktu mereka meng-hadapi kesulitan dan kesedihan. Jika orangtua menjaga jarak dengan anak maka anak akan merasa segan dan tidak dekat dengan ayah atau ibunya. ${ }^{40}$

Orangtua berperan untuk mendidik dan mengajar anak remajanya setiap saat. Waktu harus banyak dihabiskan oleh remaja bersama keluarga. Dari sinilah orangtua harus menyadari bahwa waktu bersama dengan anak merupakan waktu yang sangat penting untuk digunakan sebaik-baiknya, yaitu dengan berkomunikasi, berbagi pengalaman, mendidik, mengajarkan Firman Tuhan, membaca Alkitab bersama, dan lain-lain. Seperti yang tertulis dalam Alkitab Perjanjian Lama, Ulangan 6:6-7 "apa yang kuperintahkan kepadamu pada hari ini haruslah engkau perhatikan, haruslah engkau mengajarkannya berulang-ulang kepada anak-anakmu dan membicarakannya apabila engkau duduk di rumahmu, apabila engkau berbaring dan apabila engkau bangun”. Dari ayat Firman Tuhan ini mengingatkan dan menekankan bahwa orangtua wajib mengajarkan Firman Tuhan berulang-ulang kepada anak-anaknya, kapan saja dan di mana saja sehingga anak me-ngenal Tuhan, takut akan Tuhan, dan menaati Firman-Nya.

Mendidik anak remaja merupakan kewajiban yang harus dilakukan oleh orangtua. Glenn Clark berkata bahwa setiap anak datang ke dunia dengan membawa "surat dalam amplop yang tertutup" yang

\footnotetext{
${ }^{39}$ Ibid.

${ }^{40}$ Mary Go Setiawani, Op. Cit., 11-12.
}

artinya setiap manusia mempunyai tugas tertentu yang harus dipenuhinya. Bila seorang dilahirkan kembali dalam keluarga Allah, prinsip yang sama tetap berlaku. Rasul Paulus menjelaskan gereja sebagai Tubuh Kristus, dibekali dengan surat yang dimeteraikan (tugas khusus yang harus dipenuhinya). Sebagian tugas orangtua ialah membuka sampul yang berisi perintah itu, yaitu menolong anak menemukan kehendak Allah dalam kehidupannya. ${ }^{41}$ Orangtua bertanggung jawab untuk menjamin bahwa seorang anak benar-benar mengerti apa yang diharapkan daripadanya. Bukan saja anak itu harus memahaminya dengan akal-pikiran, tetapi ia harus ditolong bagaimana melaksanakan suatu perintah dengan benar dan memuaskan. Kebanyakan orangtua bersalah karena memberikan perintah tanpa memberikan petunjuk dengan jelas bagaimana melaksanakan perintah itu dengan tepat. ${ }^{42}$

Selain mendidik dan mengajar anak dalam hal rohani maupun pengetahuan umum, keteladanan orangtua dalam berperilaku sesuai dengan nilai-nilai Kristen akan membantu anak untuk melakukan perilaku yang sama. Perilaku-perilaku sosial yang dilakukan oleh orangtua dan anak akan membentuk kebiasaan berperilaku. ${ }^{43}$ Wibawa teladan dalam diri orangtua sangat mempengaruhi pendidikan seorang anak dibanding dengan apapun juga. ${ }^{44} \mathrm{Jadi}$, orangtua tidak hanya mendidik dan mengajar dengan kata-kata tetapi harus mempraktikkan apa yang dia ajarkan pada anak melalui tindakan.

Kaitannya dalam hal perilaku menolong adalah harus adanya peran orangtua dalam meningkatkan perilaku menolong pada remaja. Menurut penulis adapun peran orangtua dalam meningkatkan perilaku menolong adalah:

- Mengajarkan anak remaja untuk berperilaku menolong sesuai dengan ajaran

\footnotetext{
${ }^{41}$ Larry Christenson, Keluarga Kristen

(Semarang: Buku Betania, 1994), 63.

${ }^{42}$ Ibid, 64.

${ }^{43}$ Roger McIntire, Teenagers and Parents (Yogyakarta: Penerbit Kanisius, 2005), 98

${ }^{44}$ Larry Christenson, Op.Cit., 81.
} 
Alkitab. Orangtua dapat meng-ajarkan kepada anak remaja bagian ayat Alkitab yang berkata "bertolong-tolonglah menanggung bebanmu! Demikianlah kamu memenuhi hukum Kristus" (Gal.6:2). Ayat lainnya berkata: "Kasihilah sesamamu manusia seperti dirimu sendiri" (Mat. 22:39b). Selanjutnya, dalam Lukas 6:35 berkata "tetapi kamu, kasihilah musuhmu dan berbuatlah baik kepada mereka dan pinjamkan dengan tidak mengharapkan balasan, maka upahmu akan besar dan kamu akan menjadi anak-anak Allah yang Mahatinggi, sebab Ia baik terhadap orang-orang yang tidak tahu berterima kasih dan terhadap orang-orang jahat". Selain ayat-ayat Alkitab, orangtua dapat menceritakan kisah "orang samaria yang baik hati" dan menceritakan tokoh-tokoh di dalam Alkitab yang hidupnya mengasihi Allah dan mengasihi sesama.

- Mendidik remaja untuk berperilaku menolong. Contohnya, melatih remaja untuk menolong kedua orangtuanya dengan memberi tugas kecil di rumah. Seperti, seorang anak setiap pagi dapat membantu ibunya menyapu lantai jika pada saat menyapu masih ada kertaskertas yang tercecer, maka si ibu harus mengambil waktu memanggilnya kembali dan menyuruhnya mengambil setiap kertas yang tertinggal. Hal ini merupakan suatu pengalaman pendidikan untuk anak itu. Di samping itu, waktu yang sedikit yang disediakan untuk mendidiknya akan mendatangkan hasil berlipat ganda. ${ }^{45}$ Mendidik anak berperilaku menolong juga dapat dilakukan dengan mendidik anak agar tidak bersikap cuek kepada sesama, tidak egois, tidak individualistis, peka terhadap keadaan orang lain, menolong teman yang sedang dalam kesusahan, menolong orang lain yang membutuhkan pertolongan, membantu orangtuanya di rumah, dan lain-lain.

- Selain mengajarkan Firman Tuhan dan mendidik remaja, keteladan orangtua

${ }^{45}$ Ibid, 65. dalam berperilaku menolong juga sangat penting dalam meningkatkan perilaku menolong pada remaja. Salah satu faktor yang mempengaruhi perilaku menolong adalah perspektif belajar sosial di mana anak mengembangkan perilaku menolong melalui proses modeling atau peniruan terhadap orang-orang di sekitarnya, terutama perilaku menolong yang ditunjukkan oleh orang-orang yang dianggap penting atau significant-other. ${ }^{46}$ Jadi, orangtua harus menyadari bahwa perilaku menolong tidaklah hanya dengan mengajar dan mendidik tetapi juga dipraktikkan sehingga anak remaja melihat dan dapat menirunya.

\section{Peran Pendeta dalam Meningkatkan Perilaku Menolong}

\section{Pengertian Pendeta}

Pendeta adalah sebutan bagi pemimpin agama. Kata pendeta (Sanskerta: Pandita) berarti brahmana atau guru agama Hindu atau Buddha. ${ }^{47}$ Dalam agama Kristen, pendeta adalah pengajar dalam jemaat yang memiliki kewajiban untuk menentukan suasana dalam jemaat sehingga jemaat dapat lebih giat memenuhi panggilannya sebagai persekutuan belajar-mengajar. Menurut G.D. Dahlenburg, pendeta adalah hamba yang diutus Tuhan untuk melayani dan bertanggung jawab dengan apa yang Tuhan percayakan sebagai orang yang menyampaikan Injil kebenaran kepada semua orang. ${ }^{48}$

Kata pendeta tidak ditemukan dalam Alkitab. Alexander Strauch menyebutkan bahwa kata pendeta diambil dari luar Kekristenan untuk memberikan nama kepada seorang gembala tunggal atau senior yang

\footnotetext{
${ }^{46}$ Agus Abdul, Op.Cit., 226.

${ }^{47}$ Mohammad Ngajeman, Kamus Etimologi Bahasa Indonesia (Surakarta: Dahara Prize, 1986).

${ }^{48}$ Dahlenburg, Apakah Pendeta Itu? (Jakarta: BPK Gunung Mulia, 1999), 73.
} 
berkuasa ${ }^{49}$ Kata pendeta dalam Kamus Besar Bahasa Indonesia didefinisikan sebagai orang pandai, pertapa (dalam cerita-cerita kuno), pemuka, pemimpin atau guru agama. ${ }^{50}$

\section{Fungsi Pendeta}

\section{a. Pendeta Sebagai Konselor}

Dalam kaitan dengan Tritugas panggilan gereja, yaitu koinonia, konseling pastoral mempunyai peranan penting untuk menolong orang dalam pengembangan kompetensi hubungan antar manusia. Panggilan seorang pendeta dalam konseling pastoral dapat memperkuat arti dari konseling pastoral dengan beberapa alasan, antara lain:

- Pendeta adalah rekan sekerja Allah yang mengarahkan hatinya ke dalam pelayanan yang terpusat pada Allah dan setia memampukan orang lain untuk mengenal diri sendiri dan Allah.

- Pendeta mendapatkan pelayanan di dalam terang Roh Kudus dalam menjawab pergumulan-pergumulan kemanusiaan.

- Pendeta sebagai konselor pastoral selalu bersentuhan dengan apa yang disebut dengan relasi dengan sesama.

Dalam konseling pastoral seorang pendeta berkewajiban untuk memberikan konseling bagi mereka yang berada dalam kebimbangan, penderitaan dan pergumulan hidup. Konseling pastoral melalui perkunjungan membantu pendeta untuk mengetahui dengan cepat dan dapat memberikan layanan provektif sebelum seorang jatuh ke dalam masalah yang lebih berat.

Sebagai seorang konselor pastoral, yang diharapkan dari figur seorang pendeta adalah keselarasannya dalam pembimbingan dan pertolongan yang diberikan. Firman

\footnotetext{
${ }^{49}$ Alexander Strauch, Manakah yang Alkitabiah: Kepenatuaan atau Kependetaan (Yogyakarta: ANDI, 1992), 179.

${ }^{50}$ Kamus Besar Bahasa Indonesia Mobile.
}

Tuhan harus menjadi dasar dalam proses konseling pastoral dengan warga jemaat. Sebagai konselor dalam konseling pastoral, pendeta harus menempatkan warga jemaat dalam hubungan yang benar dengan Allah dan sesama. Selain itu, pendeta harus menyadari bahwa keberhasilan dalam suatu proses konseling tidak terlepas dari perannya yang menghadirkan Tuhan dan Firman-Nya yang memampukan serta melayakkan baik konselor (pendeta) maupun konseli (warga jemaat) untuk menemukan akar permasalahan dan alternatif pemecahan masalah dengan tepat.

Ketika seseorang berada dalam kebimbangan, kecemasan, keputusasaan, rasa takut yang dalam, merasa tersaing dan mengalami keterasingan, peran pendeta sebagai konselor pastoral harus dapat menyadarkan konseli akan kehadiran dan keterlibatan Tuhan Yesus berkarya dalam pergumulan dan penderitaan hidupnya, sehingga dia dipulihkan dari keterasingannya dalam keluarga, gereja, masyarakat maupun lingkungan di mana dia berada. Sentuhan tangan kasih Yesus, menempatkan seseorang berada dalam kuasa penyembuhan-Nya, yang bukan hanya membuat orang itu terbuka kepada Allah saja, tetapi kepada orang lain, lingkungan bahkan kepada diri sendiri. Keterbukaan itulah yang memberikan kehangatan spiritual agar orang mulai sadar dan perlu membangun relasi terus-menerus dengan semua orang. ${ }^{51}$

\section{b. Pendeta Sebagai Pendidik}

Pendeta memberikan dan menerangkan iman Kristen kepada anggota jemaat. Dialah yang wajib memberi teladan tentang sikap hidup dan perilaku Kristiani. Pendeta mewakili jemaatnya dan bertanggung jawab atasnya. Tuhan Yesus mengibaratkan hubungan itu dengan seorang gembala dan domba-dombanya. Sebagai seorang gembala, pendeta bukan saja mengantar kawanan dombanya, melainkan juga memberi makan

\footnotetext{
${ }^{51}$ Engel, Konseling Suatu Fungsi Pastoral (Tisara Grafika), 35-37.
} 
kepadanya, membelanya, bahkan rela menyerahkan hidupnya sendiri untuk mereka. Paulus menyinggung pula hal ini dalam surat-suratnya, sambil menegaskan bahwa dia mau memberikan seluruh pribadinya, bahkan hidupnya sekalipun untuk kepentingan jemaat jika dituntut Tuhan. ${ }^{52}$

Pendeta harus sanggup menguraikan suatu pokok dengan jelas dan menarik. Tidak cukup uraian itu jelas bagi dirinya sendiri, tetapi perlu menjadi jelas pula kepada setiap pendengarnya. Seluruh pendengarnya harus dapat mengerti dan mempelajari apa yang diajarkan pendeta kepada mereka. Terlebih pula pendeta harus merindukan supaya anggota-anggota jemaatnya maju dalam kerohanian mereka oleh pengajarannya. ${ }^{53}$

\section{Peran Pendeta dalam Meningkatkan Perilaku menolong}

Pendeta harus mengajarkan pendidikan Kristen kepada remaja. Pendidikan yang diberikan kepada remaja yang menyangkut pengetahuan (kognisi), sikap dan nilai-nilai moral, kepekaan (afeksi), serta tindakan dan keterampilan (psikomotoris, tingkah laku). Pendidikan dapat terjadi baik dalam masyarakat (misalnya gereja), keluarga, sekolah dan perguruan tinggi. ${ }^{54}$ Karena ini merupakan pendidikan agama, maka harus memusatkan perhatiannya kepada dimensi religius manusia dari perspektif Kristen. Iman Kristen dalam dimensi kognitif mencakup pengetahuan dan pengertian akan Tuhan dan kehendak-Nya seperti dinyatakan dalam Firman-Nya, tetapi juga sebagaimana dirumuskan dalam berbagai doktrin dan ajaran gereja. Iman Kristen dalam dimensi afektif mencakup hubungan pribadi dengan Tuhan, penyerahan diri, komitmen kristiani, kasih dan sikap hormat, kagum terhadap Tuhan dan ciptaan-Nya dan kehidupan spiritual. Iman Kristen dalam dimensi tinda-

\footnotetext{
${ }^{52}$ Ibid, 54.

${ }^{53}$ Homrighausen \& Enklaar, Pendidikan Agama Kristen (Jakarta: BPK Gunung Mulia, 1996), 3637.

${ }^{54}$ Daniel Nuhamara, Op.Cit., 178.
}

kan adalah pelayanan terhadap dunia dalam kasih sebagai respon terhadap mandat kerajaan Allah. ${ }^{55}$

\section{Metode Penelitian}

Metode penelitian ini adalah metode penelitian kualitatif. Penelitian kualitatif adalah penelitian yang bermaksud untuk memahami fenomena yang dialami oleh subjek penelitian, misalnya: perilaku, persepsi, motivasi, tindakan dan lain-lain secara holistik. Hasil penelitian disajikan dengan cara deskripsi dalam bentuk kata-kata dan bahasa, pada suatu konteks khusus yang alamiah dan dengan memanfaatkan berbagai metode alamiah. ${ }^{56}$ Oleh karena itu, penelitian kualitatif berhubungan dengan ide, persepsi, pendapat atau kepercayaan orang yang diteliti, yang kesemuanya itu tidak dapat diukur dengan angka-angka (data statistik). ${ }^{57}$ Artinya, penulis membuat suatu gambaran kompleks, meneliti kata-kata, laporan terinci dari pandangan informan dan melakukan studi pada situasi yang dialami.

Adapun lokasi penelitian adalah di Gereja Alkitab Anugerah Bekasi dengan alamat Ruko Mitra Bekasi Blok A8. Waktu penelitian ini direncanakan selama enam bulan yang dimulai dari bulan Januari sampai dengan Juni 2017. Teknik pengumpulan data adalah wawancara dan studi kepustakaan. Wawancara adalah percakapan dengan maksud tertentu. Percakapan itu dilakukan oleh dua pihak, yaitu pewawancara (interviewer) yang mengajukan pertanyaan dan terwawancara (interviewee) yang memberikan jawaban atas pertanyaan itu. ${ }^{58}$ Wawancara ini menjadi metode pengumpulan data yang dikerjakan dengan sistematis dan berlandaskan pada tujuan penelitian. Studi kepustakaan adalah teknik

\footnotetext{
${ }^{55}$ Ibid, 178-179.

${ }^{56}$ Lexy Moleong, Metodologi Penelitian Kualitatif (Bandung: PT. Remaja Rosdakarya, 2012), 6.

${ }^{57}$ Suwandi Basrowi, Memahami Penelitian Kualitatif (Jakarta: Rineka Cipta, 2008), 1. ${ }^{58}$ Ibid, 186.
} 
pengumpulan data yang mencakup pemikiran-pemikiran melalui pengamatan dan penelitian pada buku, literatur, catatan, dokumen, arsip, dan laporan-laporan yang berhubungan dengan objek yang akan diteliti. ${ }^{59}$ Studi kepustakaan bertujuan agar kerangka berpikir penulis berjalan sesuai koridor ilmiah dari dukungan kepustakaan, sehingga hasil pengamatan melalui pustaka relevan dengan objek penelitiannya.

Teknik sampling yang digunakan adalah menggunakan purposive sampling, karena untuk menentukan seseorang menjadi sampel didasarkan pada tujuan tertentu. Adapun yang menjadi kriteria sampel adalah sebagai berikut: 1) mereka yang mempunyai anak remaja yang suka melayani di gereja. 2) mereka yang tergolong masih sedang berkecimpung atau terlibat pada kegiatan yang tengah diteliti. 3) mereka yang punya waktu yang memadai untuk dimintai informasi. Dengan demikian jumlah sampel dalam penelitian yang sesuai dengan kriteria di atas berjumlah 13 orang dengan pembagian sebagai berikut: orangtua berjumlah 6 orang, pendeta 1 orang, dan remaja berjumlah 6 orang.

\section{TEMUAN PENELITIAN DAN ANALISIS}

\section{A. Temuan Penelitian dan Pembahasan}

Dalam penelitian yang dilakukan oleh penulis ada beberapa penemuan yang ditemukan antara lain:

- Remaja melakukan perilaku menolong didasarkan oleh karena kasih.

- Remaja melakukan perilaku menolong karena melihat teladan dari orang-orang terdekat seperti: orangtua, teman dan saudara.

- Remaja melakukan perilaku menolong karena orang tersebut pernah menolong-

\footnotetext{
${ }^{59}$ Suharsimi Arikunto, Managemen Pendidikan (Jakarta: Rineka Cipta, 2000), 76.
}

nya dan orang tersebut adalah orang yang menyenangkan bagi si penolong.

- Orangtua mengajarkan perilaku menolong melalui perkataan atau nasehat.

- Orangtua mengajarkan perilaku menolong melalui pengajaran Firman Tuhan.

- Orangtua memberikan teladan tentang sikap menolong kepada anak remajanya.

- Pendeta mengajarkan tentang perilaku menolong melalui pengajaran Firman Tuhan.

- Para informan (dalam hal ini informan adalah ibu) mengatakan bahwa tantangan atau kesulitan yang mereka hadapi ketika mendidik anak remajanya agar suka menolong antara lain: banyaknya informasi dan pengetahuan yang anak remajanya dapatkan baik di dunia nyata dan dunia maya menyebabkan nasehat orangtua terabaikan; anak remajanya terkadang masih suka memprotes ketika dinasehati dan komunikasi dari orangtua yang kurang dipahami oleh anak remajanya; penyampaian nasehat yang keras kurang diterima oleh anak remajanya; anak remajanya selalu sibuk dengan gadget; kadang-kadang anak remajanya masih memiliki sifat kekanakkanakkan, misalnya suka menunda-nunda untuk bertindak kalau dimintai tolong.

- Informan (dalam hal ini informan adalah pendeta) mengatakan bahwa tantangan atau kesulitan yang dihadapi adalah adanya pergaulan di luar gereja membuat para remaja terhalang untuk mengambil bagian dalam pelayanan di gereja; para remaja cepat terpengaruh dengan lingkungan sehingga mereka tidak konsentrasi dalam melayani dan cenderung bersikap anti sosial di dalam gereja. 


\section{B. Analisis Teologis dan Pedagogis}

\section{Analisis Teologis}

Alkitab Perjanjian Baru banyak menjelaskan tentang perilaku menolong. Salah satunya, kisah tentang orang Samaria yang baik hati. Kisah ini merupakan perumpamaan yang Tuhan Yesus sampaikan di hadapan para murid dan seorang ahli taurat yang ingin mencobai-Nya dengan sebuah pertanyaan. Matthew Henry menyatakan bahwa para guru Yahudi mempunyai gagasan yang salah mengenai perumpamaan ini. Lightfoot mengemukakan bahwa para guru Yahudi memahami ungkapan "kasihilah sesamamu manusia" dengan mengecualikan semua orang bukan Yahudi, sebab mereka bukanlah sesama orang Yahudi. Yang dimaksud dengan sesama hanyalah orangorang yang sebangsa dan seagama dengan orang Yahudi. Mereka tidak akan menghukum mati seorang Israel yang membunuh orang bukan Yahudi, sebab dia bukanlah sesama manusia. Mereka memang berkata bahwa mereka tidak boleh membunuh orang bukan Yahudi yang tidak sedang berperang dengan mereka. Tetapi, apabila mereka melihat seorang bukan Yahudi sedang sekarat, mereka tidak merasa berkewajiban untuk menyelamatkan nyawanya. Oleh sebab itu, Tuhan Yesus meluruskan gagasan yang tidak manusiawi dan menunjukkan melalui sebuah perumpamaan, di mana Tuhan Yesus ingin menyampaikan bahwa kita harus memandang semua orang yang memerlukan perbuatan baik kita sebagai sesama. ${ }^{60}$ Beberapa hal yang perlu dicermati dalam perumpamaan ini antara lain: ${ }^{61}$

- Perumpamaan itu menggambarkan kepada kita tentang seorang Yahudi malang yang mengalami kesulitan, yang ditolong dan diringankan bebannya oleh seorang Samaria yang baik hati.

- Laki-laki yang tulus sedang melakukan perjalanan dengan tenang untuk me-

\footnotetext{
${ }^{60}$ Ibid

${ }^{61}$ Ibid.
}

lakukan kegiatan yang benar. Ia melewati jalan raya antara Yerusalem dan Yerikho (ay. 30). Kedua kota itu menyiratkan bahwa ini adalah kejadian nyata, bukan sebuah perumpamaan. Bisa jadi peristiwa tersebut belum lama terjadi, tepat seperti yang diceritakan. Peristiwa-peristiwa tentang pemeliharaan Tuhan akan memberi banyak pelajaran, asalkan kita mengamatinya dengan seksama dan memanfaatkannya. Peristiwa-peristiwa seperti ini bisa dirancang menyerupai perumpamaan untuk diberikan sebagai pelajaran, dan akan lebih menyentuh. Laki-laki malang ini jatuh ke tangan penyamun-penyamun. Tidak jelas apakah ini orang-orang Arab yang hidup dari barang rampasan atau penjahat keji yang sebangsa dengannya, atau serdadu Romawi.

- Bagaimana dia diabaikan oleh orangorang yang seharusnya menjadi sahabatsahabatnya, yang bukan saja sebangsa dan seagama, tetapi juga seorang imam dan yang satu lagi seorang Lewi, tokoh-tokoh masyarakat dengan kedudukan penting. Mereka bahkan dianggap suci oleh orangorang. Tugas mereka mewajibkan mereka harus bersikap lemah lembut dan penuh belas kasihan.

- Bagaimana ia ditolong dan dirawat oleh seorang asing, yakni seorang Samaria dari suku bangsa yang paling dianggap hina dan dibenci oleh orang-orang Yahudi yang tidak mau berurusan dengan mereka. Orang Samaria ini masih memiliki perikemanusiaan dalam dirinya. Imam itu mengeraskan hatinya terhadap salah seorang dari bangsanya sendiri, tetapi orang Samaria itu membuka hati terhadap salah seorang dari bangsa lain. Ketika dia melihat orang itu, tergeraklah hatinya oleh belas kasihan dan sama sekali tidak mempermasalahkan kebangsaannya. Pertama, dia pergi kepada orang yang malang itu, yang dihindari oleh imam dan orang Lewi itu. Kedua, ia melakukan tugas seorang tabib, karena tidak ada lagi siapa-siapa di situ. Ketiga, ia menaikan 
orang itu ke atas keledai tunggangannya sendiri, sementara dia sendiri berjalan kaki, dan membawanya ke tempat penginapan. Keempat, ia merawat orang itu di penginapan, membaringkannya di tempat tidur, memberikan makanan yang layak baginya, menemaninya, dan mungkin juga berdoa dengannya. Kelima, saat berangkat keesokan paginya, dia menyerahkan uang kepada pemilik penginapan untuk dipergunakan bagi semua keperluan si sakit.

Perumpamaan yang tertulis dalam Alkitab ini memberikan pesan kepada ahli taurat dan orang-orang pada zaman sekarang bahwa sebagai seorang Kristen sudah sewajibnya untuk menunjukkan belas kasihan kepada semua orang, khususnya orang-orang yang membutuhkan pertolongan meskipun mereka tidak sebangsa dan seagama atau sependapat dan sekelompok dalam bidang kepercayaan. $^{62}$

\section{Analisis Pendidikan Agama Kristen}

Pendidikan agama Kristen berkaitan dengan suatu pengajaran. Pendidikan agama Kristen yang diajarkan kepada seseorang tidak hanya menyangkut kehidupan rohani orang tersebut tetapi juga menyangkut pengetahuan (kognitif), sikap dan nilai-nilai moral, kepekaan (afektif), serta tindakan dan keterampilan (psikomotorik). ${ }^{63}$ Jadi, dalam mengajarkan perilaku menolong kepada remaja harus menyangkut tiga hal ini, karena perilaku menolong berkaitan dengan pengetahuan (kognitif) tentang cara menolong, kepekaan untuk menolong (afektif) dan mempraktikkan tindakan atau perilaku (psikomotorik) menolong tersebut. Ketiga hal ini harus dimasukkan di dalam pendidikan yang diberikan oleh orangtua dan pendeta.

Orangtua sebagai pendidik di rumah harus benar-benar berperan sebagai pendidik dalam mengajarkan perilaku menolong.

\footnotetext{
${ }^{62}$ Ibid.

${ }^{63}$ Daniel Nuhamara, Op.Cit., 178.
}

Tanggung jawab utama dalam memberikan pendidikan ada pada orangtua. Seperti yang terlihat dalam Ulangan 6:6-7 yang menyebutkan "apa yang kuperintahkan kepadamu pada hari ini haruslah engkau perhatikan, haruslah engkau mengajarkannya berulang-ulang kepada anak-anakmu dan membicarakannya apabila engkau duduk di rumahmu, apabila engkau sedang dalam perjalanan, apabila engkau berbaring dan apabila engkau bangun." Drescher menekankan bahwa orangtua memberikan pendidikan kepada anak agar membuat anak percaya kepada Tuhan, tidak akan melupakan tindakan Tuhan, dan supaya anak tidak menjadi liar, keras kepala, atau melawan. ${ }^{64}$ Heath juga menjelaskan bahwa dilihat dari pola pendidikan umat Israel, maka hal yang harus diperhatikan adalah siapa yang bertugas untuk mendidik, isi pengajaran, dan konteks pendidikan. Yang bertanggung jawab atas pendidikan itu adalah orangtua sendiri, terutama ayah. Anak-anak harus dididik dalam konteks kekeluargaan. Ibu boleh mendidik anak, tetapi ayahlah yang bertanggung jawab atas pendidikan itu. Tanggung jawab yang lain diberikan kepada pendeta dan guru di sekolah. ${ }^{65}$ Orangtua harus mengajarkan perilaku menolong agar remaja bisa menghargai, menghormati dan mengasihi sesama karena pengajaran itu akan berdampak pada kehidupan sosialnya baik dalam keluarga maupun gereja dan masyarakat. Homrighausen menekankan supaya di dalam keluarga anak-anak belajar mengasihi sesama dan berkorban, serta menolong yang lebih lemah atau berkekurangan. ${ }^{66}$

Tidak hanya orangtua, pendeta sebagai pendidik di gereja harus benar-benar berperan sebagai pendidik untuk mengajarkan kepada jemaat tentang segala hal yang menyangkut kerohanian seseorang dengan Tuhan, pengetahuan tentang Allah dan sikap-

\footnotetext{
${ }^{64}$ John Drescher. Tujuh Kebutuhan Anak (Jakarta: BPK Gunung Mulia, 1997), 123.

${ }^{65}$ Stanley Heath, Teologi Pendidikan Anak Dasar Pelayanan Kepada Anak (Bandung: Kalam Hidup, 2005), 29.

${ }^{66}$ Homrighausen \& Enklaar, Op.Cit., 131.
} 
sikap yang sesuai dengan nilai-nilai Kristen. Homrighausen dan Enklaar menyatakan bahwa pendeta memimpin segala pekerjaan dalam jemaat, untuk menggiatkan gerak jemaat. Oleh sebab itu, sangat penting seorang pendeta mengajarkan pendidikan agama bagi jemaat. ${ }^{67}$ Jadi, pendeta harus mendidik remaja perilaku menolong di dalam gereja, misalnya memberikan pengertian tentang apa itu perilaku menolong; pentingnya perilaku menolong dalam keluarga, gereja dan masyarakat; pentingnya perilaku menolong karena perilaku tersebut sesuai dengan nilai-nilai Kristen. Kemudian pendeta juga harus memberikan pendidikan yang menyangkut kepekaan (afektif), seperti memberikan renungan agar remaja menyadari betapa mulia tindakan menolong tersebut. Pendeta harus melatih dan memberi motivasi kepada remaja agar mereka mempraktikkan perilaku menolong.

Lingkungan belajar juga dapat mempengaruhi perilaku seseorang dengan cara-cara tertentu yang mempengaruhi tingkah laku, pertumbuhan dan perkembangannya. ${ }^{68}$ Belajar adalah proses untuk memperoleh suatu perubahan tingkah laku yang baru secara keseluruhan. ${ }^{69}$ Dari hasil wawancara kepada orangtua, pendeta dan remaja, tampak bahwa dalam menerapkan perilaku menolong, lingkungan belajar mempengaruhi remaja dalam berperilaku.

Model pendidikan yang diberikan orangtua dan pendeta dalam meningkatkan perilaku menolong pada remaja antara lain model pendidikan dalam bentuk lisan, yaitu orangtua memberikan nasihat-nasihat secara umum kepada remaja agar melakukan tindakan menolong. Model lain adalah keteladanan dalam melakukan tindakan menolong kepada orang lain sehingga secara tidak langsung tindakan ini telah memberi contoh kepada remaja. Pengajaran Firman

\footnotetext{
${ }^{67}$ Ibid., 55.

68 Ngalim Purwanto, Ilmu Pendidikan Teoritis dan Praktis (Bandung: PT. Remaja Rosda Karya, 1995), 72.

${ }^{69}$ Slamento, Belajar dan Faktor-faktor yang Mempengaruhinya (Jakarta: PT. Rineka Cipta, 1995), 2.
}

Tuhan merupakan model pengajaran di mana orangtua mengajarkan tindakan menolong dengan mengutip ayat Firman Tuhan yang berkaitan dengan menolong sesama manusia. Model evaluasi juga bisa digunakan dalam mengajar perilaku menolong pada remaja. Dalam arti luas, evaluasi adalah suatu proses merencanakan, memperoleh, dan menyediakan informasi yang sangat diperlukan untuk membuat alternatif-alternatif keputusan. Sesuai dengan pengertian tersebut maka setiap kegiatan evaluasi atau penilaian merupakan suatu proses yang sengaja direncanakan untuk memperoleh informasi atau data. Berdasarkan data tersebut kemudian dicoba membuat suatu keputusan. ${ }^{70}$ Model evaluasi yang dimaksud adalah model evaluasi dalam bentuk memberikan penghargaan. Jadi, jika ada anak yang berbuat baik kepada sesamanya, orangtua harus memberikan penghargaan berupa pujian atau hadiah kecil yang memberikan makna bagi seorang remaja bahwa tindakannya sangat terpuji dan berarti.

Perkembangan perilaku remaja harus menjadi perhatian orangtua dan pendeta, termasuk perilaku menolong. Karena jika remaja sudah tidak melakukan perilaku menolong maka itu akan mempengaruhi kehidupan pribadi, keluarga, dan masyarakat di sekolah, gereja dan masyarakat. Jika hal ini diabadaikan, maka secara pribadi, remaja akan menjadi anak yang cuek, tidak peka terhadap kesusahan yang dialami orang lain, bahkan dia dapat menjadi anak remaja yang suka menjerumuskan temannya ke dalam halhal yang negatif, misalnya, mengajak teman untuk merokok, minum minuman keras, menggunakan narkoba, mengajak ke diskotik, dan lain-lain. Dalam kehidupan keluarga, remaja tidak mau menolong baik orangtua maupun saudara-saudaranya sehingga membuat remaja ini terkesan pelit di dalam keluarga, membuat hubungan antara orangtua dengan si remaja tidak akrab, membuat orangtua dan remaja bertengkar, membuat orangtua jadi kesal dan marah-

\footnotetext{
${ }^{70}$ M. Ngalim Purwanto, Prinsip-Prinsip dan Teknik Evaluasi Pengajaran (Bandung: PT. Remaja Rosdakarya, 1994), 3.
} 
marah, dan lain-lain. Dalam kehidupan sosial di sekolah, remaja akan disebut anak yang pelit, cuek, anti sosial sehingga dia dijauhi oleh teman-temannya bahkan tidak ada yang mau bergaul dengan dia, dan lain-lain. Di gereja, remaja tidak dapat mengembangkan talenta yang ada dalam dirinya, dan bersikap pasif dalam pelayanan. Di masyarakat, remaja dapat dicap anak yang sombong karena tidak suka menolong orang yang di sekitarnya. Tidak hanya berdampak dalam hubungan dengan sesama manusia, tetapi juga berdampak pada hubungan kerohanian antara remaja dan Tuhan. Ketika seorang remaja tidak mau menolong atau mengasihi sesama, sama halnya dia tidak mengasihi Tuhan karena Alkitab berkata "karena barangsiapa yang tidak mengasihi saudaranya yang dilihatnya, tidak mungkin mengasihi Allah yang tidak dilihatnya" (1 Yoh. 4:20b). Oleh sebab itu, sangat perlu mengajarkan tindakan menolong pada anak remaja di dalam pendidikan agama Kristen. Karena masa remaja adalah masa yang baik bagi dia untuk menerima pengajaran perilaku menolong yang akan berlaku sampai masa tuanya.

Kurikulum dan Rencana Pelaksanaan Pembelajaran perlu dirancang dengan baik untuk mengajarkan perilaku menolong. Penyusunan kurikulum itu sendiri dapat melibatkan pendeta, penatua atau diaken yang berkompeten di bidang pendidikan, serta guru dan warga jemaat yang memiliki latar belakang pendidikan di bidang PAK.

Berdasarkan hasil wawancara dan observasi di Gereja Alkitab Anugerah Bekasi, penulis melihat bahwa gereja tersebut belum memiliki program-program yang dapat meningkatkan perilaku menolong. Oleh sebab itu, penulis mengusulkan agar gereja merancang program-program yang dapat dipakai untuk pembelajaran kepada remaja khususnya menyangkut perilaku menolong. Pendeta dan penatua harus mengambil waktu untuk mengajak para remaja mengunjungi anak yatim piatu di panti asuhan; mengajak para remaja membantu membersihkan rumah anggota jemaat yang dilanda banjir; membuat pelayanan remaja di panti asuhan dan berpartisipasi memberikan sumbangan berupa pakaian, makanan dan lain-lain kepada anak yatim piatu. Pendeta bisa mengajak para remaja untuk melakukan pelayanan di rumah sakit, lembaga pemasyarakatan dan lain-lain.

\section{Kesimpulan}

1. Perilaku menolong merupakan seluruh tindakan yang berhubungan dengan memberikan bantuan kepada orang lain melalui pikiran, perkataan dan perbuatan dengan tujuan meringankan beban orang lain dan memberi jalan keluar dari kesulitan dan masalah orang tersebut. Adapun bentuk-bentuk perilaku menolong yang dilakukan remaja antara lain perilaku menolong yang bersifat langsung, seperti: membantu orangtua di dalam pekerjaan rumah, mengantar orangtua ke gereja, mengantar orangtua kemana saja sesuai keperluan, membagikan uang jajan kepada teman yang tidak punya uang jajan, membantu orangtua dalam hal keuangan, mengajak teman untuk datang beribadah, membantu pelayanan di gereja. Kemudian perilaku menolong yang dilakukan oleh remaja yang bersifat tidak langsung, seperti: memberikan bantuan berupa barang dan uang kepada korban bencana alam melalui organisasi sekolah, menyumbangkan uang kepada teman yang orangtuanya meninggal melalui organisasi gereja dan sekolah dan perilaku menolong yang bersifat serius, seperti mendonorkan darah yang dilakukan di sekolah.

2. Peran orangtua dalam meningkatkan perilaku menolong pada remaja, antara lain: sebagai pendidik, yaitu orangtua bertanggung jawab untuk mendidik remaja di dalam keluarga untuk berperilaku menolong melalui nasehat tentang perilaku menolong, dorongan untuk berperilaku menolong, dan pengajaran akan Firman Tuhan yang berkaitan 
dengan perilaku menolong. Sebagai tokoh teladan, yaitu orangtua menjadi tokoh yang ditiru oleh remaja dalam melakukan tindakan menolong. Orangtua tidak hanya sekedar memberi nasehat dan pengajaran, tetapi juga mempraktikkan perilaku menolong tersebut. Sebagai pembimbing, orangtua membimbing dalam hal mengamati dan memperhatikan perilaku menolong remaja.

3. Peran pendeta dalam meningkatkan perilaku menolong pada remaja antara lain: sebagai guru, pendeta mengajarkan Firman Tuhan dan memberi motivasi kepada remaja untuk melakukan tindakan menolong. Sebagai tokoh teladan, pendeta menjadi tokoh bagi remaja dalam hal melakukan tindakan menolong sehingga remaja tersebut dapat meniru teladan pendeta.

4. Dampak pendidikan agama Kristen yang diajarkan orangtua berupa nasehat, teladan dan pengajaran Firman Tuhan membuat remaja terdorong untuk melakukan tindakan menolong baik dalam keluarga, sekolah dan masyarakat. Seperti halnya pendidikan agama Kristen yang diajarkan oleh pendeta melalui pengajaran Firman Tuhan, membuat para remaja dapat membantu pelayanan di gereja. Misalnya pelayanan musik, singer, operator LCD, penerima tamu, pembawa persembahan.

\section{Daftar Pustaka}

Alkitab. Jakarta: Lembaga Alkitab Indonesia, 2010.

Arikunto Suharsimi. Managemen Pendidikan. Jakarta: Rineka Cipta, 2000.

Basrowi Suwandi. Memahami Penelitian Kualitatif. Jakarta: Rineka Cipta, 2008.

Boehlke Robert. Sejarah Perkembangan Pikiran \& Praktek Pendidikan Agama
Kristen: dari Plato sampai I.G Loyola. Jakarta: BPK Gunung Mulia, 2011.

Boehlke Robert. Sejarah Perkembangan Pikiran dan Praktek Pendidikan Agama Kristen: dari Yohanes Amos Comenius sampai Perkembangan PAK di Indonesia. Jakarta: BPK Gunung Mulia, 2010.

Byrne \& Baron. Social Psychology. New York: Pearson Education, 2003.

Carter Clark. Quantitative Psychological Research: A Student's Handbook. USA and Canada: Psychology Press, 2004.

Christenson Larry. Keluarga Kristen. Semarang: Buku Betania, 1994.

Dahlenburg. Apakah Pendeta Itu? Jakarta: BPK Gunung Mulia, 1999.

Drescher John. Tujuh Kebutuhan Anak. Jakarta: BPK Gunung Mulia, 1997.

Engel, Konseling Suatu Fungsi Pastoral. Tisara Grafika.

Heath Stanley. Teologi Pendidikan Anak Dasar Pelayanan Kepada Anak. Bandung: Kalam Hidup, 2005.

Homrighausen E.G \& Enklaar I.H. Pendidikan Agama Kristen. Jakarta: BPK Gunung Mulia, 1996.

Hurlock Elizabeth. Psikologi Perkembangan. Jakarta: Erlangga, 1999.

Jariah, Jurnal Pendidikan Agama Kristen. Toraja: STAKN, 2014.

Kassin \& Brehm. Social Psychology. USA: Houghton Mifflin Co, 1996.

Kristianto Lilik Paulus. Prinsip dan Praktik Pendidikan Agama Kristen. Yogyakarta: ANDI, 2006.

Kristya Mesach. diktat Konseling Pastoral. Salatiga, 2007.

McIntire Roger. Teenagers and Parents. Yogyakarta: Penerbit Kanisius, 2005.

Milla Virgil John. Peran Keluarga Dalam Pendidikan Agama Kristen Terhadap Pertumbuhan Rohani Anak. YAKI, 2012.

Moleong Lexy. Metodologi Penelitian Kualitatif. Bandung: PT. Remaja Rosdakarya, 2012. 
Ngajeman Mohammad. Kamus Etimologi

Bahasa Indonesia. Surakarta: Dahara

Prize, 1986.

Notohamidjojo. Kreativitas yang bertanggung jawab. Salatiga: LPIS, IKIP Kristen Satyawacana Bagian II, 1973.

Nuhamara Daniel. Pembimbing Pendidikan Agama Kristen. Jabar: Jurnal Info Media, 2009.

Paranouan M. Psikologi Pendidikan Agama Kristen. Rantepao: Percetakan Sulo, 1995.

Piliavin, Dovidio, Schroeder \& Penner. The Psychology of Helping and Atruism USA: Mcgraw Hill, 1995.

Purwanto Ngalim. Ilmu Pendidikan Teoritis dan Praktis. Bandung: PT. Remaja Rosda Karya, 1995.

Rahman Abdul Agus. Psikologi Sosial. Jakarta: Raja Grafindo Persada, 2014.

Setiawani Go Mary. Menerobos Dunia Anak. Bandung: Kalam Hidup, 2000.

Slamento. Belajar dan Faktor-faktor yang Mempengaruhinya. Jakarta: PT. Rineka Cipta, 1995.

Soeparno bin Koentjoro. Psychology Human Development. Malaysia: Universitas Kebangsaan Malaysia, 2013.

Strauch Alexander, Manakah yang Alkitabiah: Kepenatuaan atau Kependetaan. Yogyakarta: ANDI, 1992.

Sukardi. Metodologi Penelitian Pendidikan. Jakarta: Bumi Aksara, 2011.

Sugiyono. Metode Penelitian Pendidikan. Bandung: Alfa Beta, 2012.

Wijanarko Jarot. Mendidik Anak. Jakarta: Suara Pemulihan, 2006.

Yulia Singgih \& Singgih Gunarsa. Psikologi Perkembangan Anak dan Remaja. Jakarta: BPK Gunung Mulia, 2008.

http://dunia-narkoba.blogspot.com

http://smslap.ditjenpas.go.id/public/grl/detail/ daily/upt/db6103f0-6bd1-1bd1-cadc313134333039

http://tvonenews.tv/arsip/view/62132/2012/0 $9 / 27 /$ 